\title{
Benign Giant Cell Tumor of the Foot Originating from Talonavicular Joint*
}

\author{
Hakan Cift $^{1 \#}$, Korhan Ozkan ${ }^{1}$, Serkan Senol ${ }^{2}$, Esat Uygur ${ }^{1}$, Harzem Ozger $^{3}$ \\ ${ }^{1}$ Department of Orthopaedic and Traumatology, Goztepe Education and Research Hospital, Istanbul Medeniyet University, İstanbul, \\ Turkey; ${ }^{2}$ Department of Pathology, Goztepe Education and Research Hospital, Istanbul Medeniyet University, İstanbul, Turkey; \\ ${ }^{3}$ Department of Orthopaedic and Traumatology, İstanbul Faculty of Medicine, Istanbul University, İstanbul, Turkey. \\ Email: $\left\{{ }^{\#}\right.$ hakanturancift, drserkansenol, harzemo\}@yahoo.com, \{korhanozkan, esatuygur\}@hotmail.com
}

Received March 15 ${ }^{\text {th }}, 2012$; revised April 20 $0^{\text {th }}, 2012$; accepted May $18^{\text {th }}, 2012$

\begin{abstract}
Benign Giant Cell Tumor is a relatively common benign lesion which usually appears as an enlarging painless mass and has a synovial origin. Although benign giant cell tumors generally involve tendon sheaths, they are infrequently documented in the foot. A 45 years old female presented with a complaint of a lump on the top of her left foot. Under general anesthesia with a pneumatic tourtniquet the mass excised with great care not to leave any residual tumor tissue that can cause recurrence. Benign giant cell tumor of the foot can be associated with talonavicular joint capsule which can be detected with MRI imaging and total excision of the lesion is mandatory to prevent recurrence.
\end{abstract}

Keywords: Giant Cell Tumor; Talonavicular Joint

\section{Introduction}

Benign Giant Cell Tumor is a relatively common benign lesion which usually appears as an enlarging painless mass and has a synovial origin [1]. Although benign giant cell tumors generally involve tendon sheaths, they are infrequently documented in the foot. They can very rarely take their origin from capsular tissues [2]. The lesions are most commonly seen in females between third and fifth decades of life [3]. This tumor is encased in a membrane and usually migrates along the tendon sheath. Since remaining portions of this benign tumor tend to reoccur locally during surgery all tumor tissue should be removed [4].

\section{Case Report}

A 45 years old female presented with a complaint of a lump on the top of her left foot (Figure 1). The patient had no history of trauma with the mass occured 1.5 years ago which then the lesion became progressively larger. Physical examination of her left foot revealed a firm, raised lesion approximately $1.5 \mathrm{~cm}$ in diameter located on tibialis anterior tendon over the dorsum of her foot. X ray examination of the patient's foot displayed no osseous or articular abnormalities. Magnetic resonance imaging revealed soft tissue mass originating from the talonavicular

\footnotetext{
*Competing interest: The authors declare that they have no competing interests.

\#Corresponding author.
}

joint. No bony involvement was noted (Figure 2).

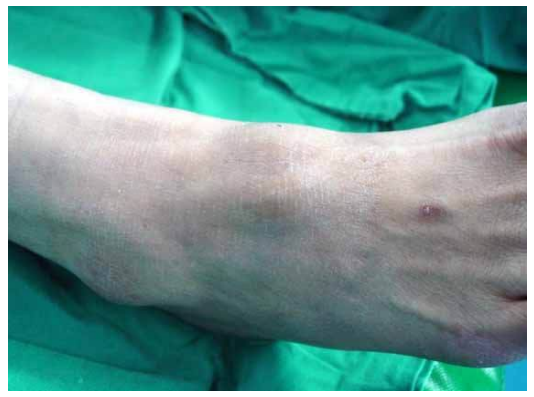

Figure 1. The patient presented with a complaint of a lump on the top of her left foot.

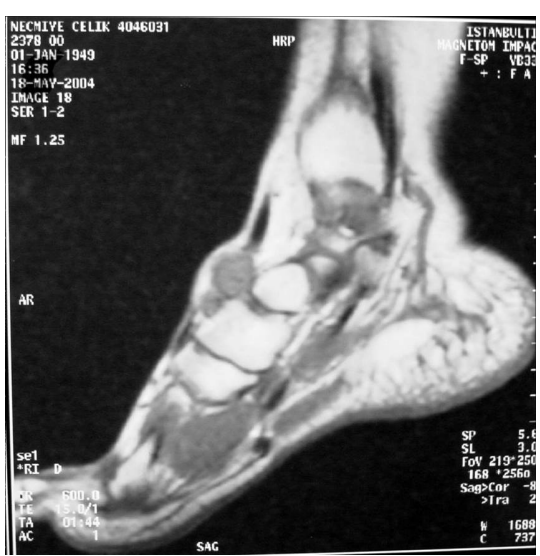

Figure 2. MRI of the patient's foot. 
Biopsy was done with trucut needle. Microscopic examination revealed multinucleated giant cells, lipid laden foam cells and round stromal cells in a collegenous stroma. The diagnosis was benign giant cell tumor and surgery was decided.

Under general anesthesia with a pneumatic tourniquet linear $3 \mathrm{~cm}$ incision was made over the dorsum of the foot. Tibialis anterior tendon was found to be compressed by the lesion and the lesion was noted to be originating from the talonavicular joint capsule. Then the mass excised with great care not to leave any residual tumor tissue that can cause recurrence (Figure 3).

Postoperatively, active range of ankle and foot motion was begun since the tibialis anterior tendon was not destroyed by the tumor. Then the patient was scheduled for follow up with MRI imaging to monitor for recurence and she had no recurrence at her last visit 2 years after the surgery.

\section{Discussion}

Giant cell tumour of the tendon sheath (GCTTS), fibrous histocytoma of synovium, pigmented nodular synovitis, tenosynovial giant cell tumour, localised nodular tenosynovitis, benign synovioma, and fibrous xanthoma of the synovium are all names for the same disease. GC-TTS is the second common benign tumour of the hand after ganglion and sites, such as the feet, knees and others, can also be involved [5-7]. It is a lesion of unknown nature and has a high recurrence rate, which could be as high as $30 \%$ [8] (Figure 4).

The benign giant cell tumor in this case report is unique so as to originate from the talonavicular joint capsule and not being associated with the tendon sheath of tibialis anterior tendon. In the literature there is only one case report about the benign giant cell tumor originating from joint capsule of the foot which is the calcenocuboid joint. MRI proved to be the most useful preoperative investigation as giant cell tumor has a characteristic appearance of areas of low signal intensity on both T1- and T2-

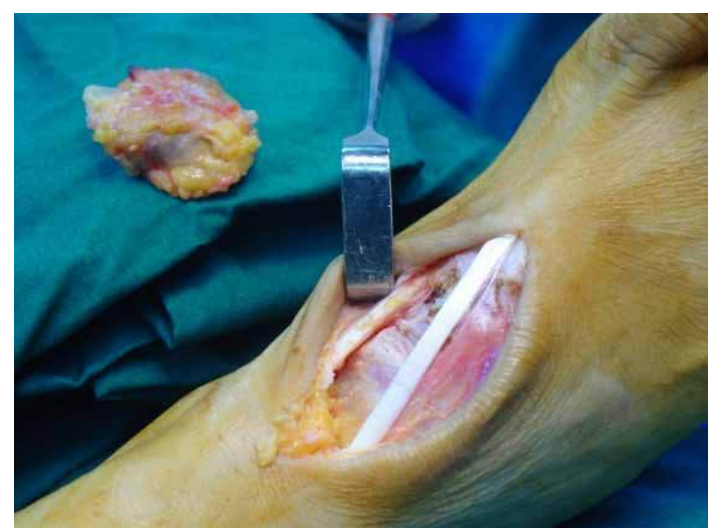

Figure 3. The mass on the dorsum of the foot.

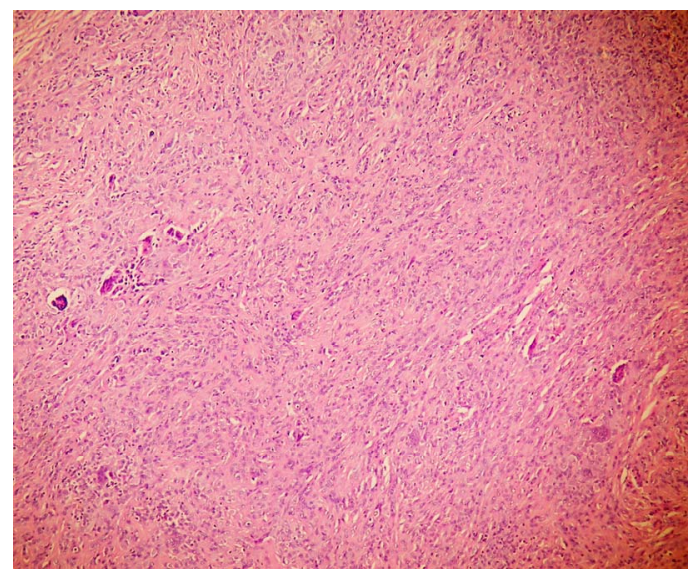

Figure 4. Variable proportions of mononuclear cells (small, round to spindled, with pale cytoplasm and round or grooved nuclei), osteoclast-like giant cells with 3 - 50 nuclei, foam cells, epithelioid cells with glassy cytoplasm and round ve-sicular nuclei and Stroma is hyalinized dense fibrous (hematoxylin and eosin, original magnification $\times 100$ ).

weighted images due to the paramagnetic effect of hemosiderin which can help in differential diagnosis and surgical planning.

Benign giant cell tumor of the foot can be associated with talonavicular joint capsule and it should be thought in differential diagnosis of this region's lesions. Benign giant cell tumor can be detected with MRI imaging and total excision of the lesion is mandatory to prevent recurrence.

\section{Consent}

Written informed consent was obtained from the patient for publication of this case report and accompanying images. A copy of the written consent is available for review by the Editor-in-Chief of this journal.

\section{Acknowledgements}

No funding has been received for the study.

\section{REFERENCES}

[1] R. Eisenstein, "Giant Cell Tumor of Tendon Sheath," Journal of Bone and Joint Surgery, Vol. 50A, 1968, pp. 476-485.

[2] F. M. Enzinger and S. W. Weiss, "Benign Tumors and Tumor-Like Lesions of Synovial Tissue," In: F. M. Enzinger and S. W. Weiss, Eds., Soft Tissue Tumors, Mosby Publisher, Missouri, 1988, pp. 639-645.

[3] B. Yanklowitz, "Giant Cell Tumor of Tendon Sheath," Journal of the American Planning Association, Vol. 68, No. 10, 1978, pp. 706-711.

[4] B. W. Butler and J. M. Mccarty, "Benign Giant Cell Tumor of the Foot," The Journal of Foot and Ankle Surgery, Vol. 32, No. 3, 1993, pp. 299-304. 
[5] C. Villani, G. Tucci, M. Di Mille, S. Di Gennaro and A. Corsi, "Extra-Articular Localized Nodularsynovitis (Giant Cell Tumor of Tendon Sheath) Attached to the Subtalar Joint," Foot Ankle International, Vol. 17, No. 7, 1996, pp. 413-416.

[6] D. G. Sheppard, E. E. Kim, A. W. Yasko and A. Ayala, "Giant Cell Tumor of the Tendon Sheath Arising from the Posterior Cruciate Ligament of the Knee: A Case Report and Review of the Literature," Clinical Imaging, Vol. 22, No. 6, 1998, pp. 428-430. doi:10.1016/S0899-7071(98)00030-8
[7] L. Thaxton, A. F. AbuRahma, H. H. Chang and J. P. Boland, "Localized Giant Cell Tumor of Tendon Sheath of Upper Back," Surgery, Vol. 118, No. 5, 1995, pp. 901903. doi:10.1016/S0039-6060(05)80282-X

[8] A. S. Rao and V. J. Vigorita, "Pigmented Villonodular Synovitis (Giant Cell Tumor of the Tendon Sheath of the Synovial Membrane). A Review of Eighty One Cases," Journal of Bone and Joint Surgery, American Volumn, Vol. 66, No. 1, 1984, pp. 76-94. 